\title{
Cultural and Morphological Variability in Sclerotium rolfsii Causing Stemrot Disease
}

\author{
V. Karthik Pandi ${ }^{*}$, C. Gopalakrishnan ${ }^{2}$ and V. Janahiraman ${ }^{3}$ \\ ${ }^{1}$ Department of Plant pathology, TNAU, Coimbatore-641003, India \\ ${ }^{2}$ Agricultural College and Research Institute, Kudumiyanmalai, India \\ ${ }^{3}$ Department of Microbiology, Agricultural College and Research Institute, Madurai, India \\ *Corresponding author
}

\begin{tabular}{|c|c|}
\hline \multicolumn{2}{|r|}{ A B S T R A C T } \\
\hline & \multirow{7}{*}{ 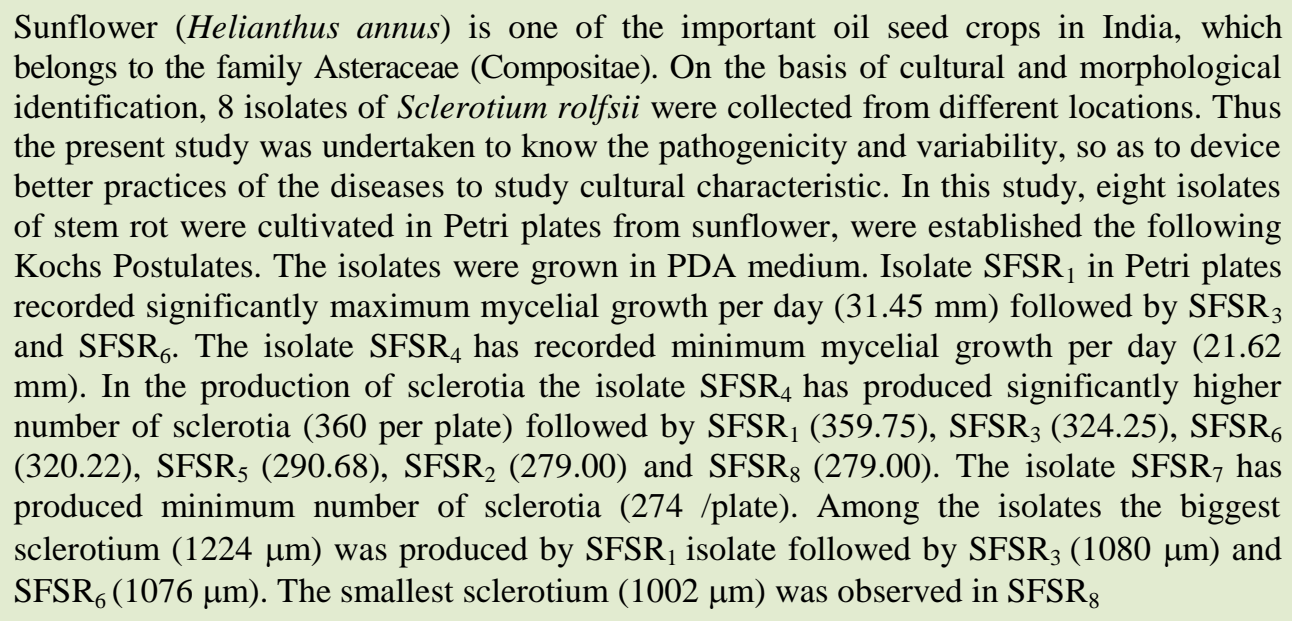 } \\
\hline & \\
\hline & \\
\hline & \\
\hline Ar & \\
\hline $\begin{array}{l}\text { Accepte } \\
29 \text { May } \\
\text { Availab } \\
10 \text { June }\end{array}$ & \\
\hline & \\
\hline
\end{tabular}

\section{Introduction}

Sunflower (Helianthus annus) is one of the important oil seed crops in India, which belongs to the family Asteraceae (Compositae). In India it is grown in an area of about 7,20,000 hectares with an annual grain production of 5,00,000 tonnes (Anonymous, 2012). In Tamil Nadu it is cultivated in 20,000 hectares with a production of 30,000 tonnes (Anonymous, 2012). The crop has shown distinct superiority over other oil seed crops owning to its wider adaptability to different agro climatic conditions, high potential yield per unit area, short duration and ability to withstand drought. Diseases are one of the important factors limiting the productivity of sunflower. Among them stem rot caused by Sclerotium rolfsii is an important disease.

S. rolfsii is a soil-borne pathogen capable of infecting wide range of crops especially during reproductive stage of the crop. Among the crops viz., soybean, peanut, sugar beet, pepper, tomato and potato suffer maximum losses, whereas sorghum, wheat, rice, lentil, betel vine, alfalfa, cotton, sugarcane, tobacco, sunhemp, sunflower, chrysanthemum, gladiolus 
and other ornamental species suffer minor damage (Ansari, 2005). Garren (1961) has estimated the losses due to $S$. rolfsii to the extent of 10 to 20 million dollars annually in southern USA. The yield loss up to 75 to 80 per cent has been reported in New Mexico (Aycock, 1966). In severely infected field, loss ranges from 10 to 25 per cent and sometimes, it reaches up to 80 per cent (Mehan and McDonald, 1990). In India, stem rot caused by $S$. rolfsii is a major problem in most of the states accounting for 10-11 per cent yield loss (Santha lakshmi Prasad et al., 2012). The typical symptom of the disease is rapid wilting and sickly appearance of plants with brownish lesion at the stem base near the soil lane which later girdles the stem. White mycelial growth forms over the infected tissue and often radiates over the soil surface.

\section{Materials and Methods}

\section{Isolation and identification of Sclerotium rolfsii}

Stem rot infected sunflower plants were collected from different fields situated in Coimbatore, Erode, Tiruppur, Dindugal, Karur, Thothukudi, Trichy in Tamil Nadu. The stem rot infected sunflower plants collected during disease survey were initially washed with tap water. The part of collar or stem region showing typical symptoms of the disease was cut into small pieces. These pieces were surface sterilized with $0.1 \%$ mercuric chloride solution for 30 seconds. Such pieces were washed thoroughly in sterile distilled water thrice to remove traces of mercuric chloride, if any and then aseptically transferred to sterilized potato dextrose agar (PDA) plates. They were incubated at $27 \pm 1^{\circ} \mathrm{C}$ for three days for the growth of the fungus. Later, loopfull of fungal growth was transferred to PDA slants. The fungus was further purified by hypal tip method under aseptic conditions (Rangaswamy, 1972). Totally 8 isolates of $S$. rolfsii were purified and used for further studies. Stem rot identification was based on morphological characters such as colony morphology, mycelial growth rate, scleortial number, size and colour, were observed measurement of 100 sclerotia was taken under the microscope (Magnification $45 \mathrm{x} \times 10 \mathrm{x}$ ) by using ocular and stage micrometers.

\section{Proving the pathogenicity and virulence}

Sterilized soil was taken in earthen pots of size $45 \times 30 \mathrm{~cm}$. Thirty days old culture of each isolate grown on sand corn meal medium was mixed thoroughly with four per cent (w/w basis). Then apparently healthy, surface sterilized sunflower seeds (Morden, KBSH44 variety) were planted in pots filled with culture. Plants in pots without inoculum served as control. Soil moisture was maintained at 25 per cent moisture holding capacity of soil by adding sterilized water on weight basis throughout the period and five plants were maintained in each pot. After 30 days of inoculation, the plants showing the typical wilting symptoms were observed. Re isolation was made from such affected portion of the plant tissue and compared with that of original isolate for conformity. The stem rot incidence caused by each isolates of $S$. rolfsii on both Morden and KBSH-44 were recorded.

\section{Cultural and morphological study of stem rot Sclerotium rolfsii}

The isolate of Sclerotium rolfsii were grown in Potato Dextrose Agar (PDA) for morphological Variation of Culture. The isolates were inoculated in PDA media to study growth of culture and formation of sclerotia.

\section{Morphological variations}

The experiment was conducted in order to study the variation in the morphological characters of different isolates of S. rolfsii. 
For this purpose, $15 \mathrm{ml}$ of potato dextrose agar was poured into Petri plates. Mycelial disc of seven day old culture of the respective isolates was placed at the centre of the plate. Three replications were maintained at room temperature $\left(27 \pm 1^{\circ} \mathrm{C}\right)$ for three days and colony character like diameter, pigmentation, radial growth and concentric rings were recorded. To get matured sclerotial bodies, the cultures were further incubated up to thirty days. For each isolate, diameter of ten sclerotial bodies per replication was recorded with the help of screw gauge and observations were statistically analysed. The total number of sclerotia produced per $\mathrm{cm}^{2}, 100$ sclerotial test weight and shape of sclerotia of individual isolate were also recorded and analysed statistically. The growth and morphological characters of the isolates viz., colony morphology, mycelial growth rate, scleortial number, size and colour, were observed, Measurement of 100 sclerotia was taken under the microscope (Magnification $45 \mathrm{x} \times 10 \mathrm{x})$ by using ocular and stage micrometers.

\section{Results and Discussion}

\section{Disease survey}

Disease survey was conducted during kharif (June-October 2012) in major sunflower growing districts during vegetative and late flowering stages. Occurrence of Alternaria leaf spot and powdery mildew was moderate in most places of the survey. In general, powdery mildew incidence was recorded during grain filling stage of the crop. There was no incidence of rust throughout the state during Kharif season. Necrosis disease was observed in all the regions in the range of 1.0 - 3.3 per cent. Wet root rot of sunflower caused by $S$. rolfsii was observed at grain filling stage in all the regions during the survey. The maximum incidence of stem rot $(5.5 \%)$ was recorded in Dindugal district followed by Erode district $(5 \%)$. The lowest incidence was recorded in Tuticorin district. Stem rot infected sunflower plants were collected during the survey and brought to the laboratory and used for isolation of S. rolfsii (Table 1 and Plate 1).

\section{Isolation of the pathogen and pathogenicity studies}

Totally eight isolates of $S$. rolfsii were isolated from the sunflower plants collected during the disease survey and used for morphological variability studies. List of isolates used in the study were furnished in (Table 2).

There were significant differences among the eight isolates of $S$. rolfsii with respect to their virulence. The isolate $\mathrm{SFSR}_{3}$ was found more virulent than other isolates. It recorded the maximum stem rot incidence of 55.44 and 68.82 in Morden and KBSH-44 respectively. The isolate $\mathrm{SFSR}_{8}$ was less virulent among the isolates. Hence $\mathrm{SFSR}_{3}$ isolate was selected and used for epidemiological and management studies (Table 3; Plate 2 and Fig. 1).

\section{Morphological character mycelial growth}

Among the eight isolates studied, three isolates namely $\mathrm{SFSR}_{2}, \mathrm{SFSR}_{3}$ and $\mathrm{SFSR}_{6}$ have produced fluffy, dull white colonies, while other isolates produced compact and dull white colonies. The mycelial growth of eight isolates of $S$. rolfsii were studied and isolate $\mathrm{SFSR}_{1}$ recorded significantly maximum mycelial growth per day (31.45 $\mathrm{mm}$ ) followed by $\mathrm{SFSR}_{3}$ and $\mathrm{SFSR}_{6}$, which recorded 27.52 and $26.53 \mathrm{~mm}$ growth per day respectively. The isolate $\mathrm{SFSR}_{4}$ has recorded minimum mycelial growth per day (21.62 mm) (Table 4 and Plate 3, 4).

\section{Sclerotial colour}

All the eight isolates produced sclerotial bodies and its colour was grouped under three 
categories viz., light brown, dark brown and reddish brown. The isolates $\mathrm{SFSR}_{7}$ and $\mathrm{SFSR}_{8}$ produced reddish brown sclerotial body. Isolate $\mathrm{SFSR}_{2}, \mathrm{SFSR}_{3}, \mathrm{SFSR}_{5}$ and $\mathrm{SFSR}_{6}$ produced the dark brown coloured scleorita. Isolate $\mathrm{SBSR}_{5}$ produced light brown coloured sclerotial bodies (Table 4 and Plate 5).

\section{Sclerotial number}

Isolate $\mathrm{SFSR}_{4}$ has produced significantly higher number of sclerotia (360 per plate) followed by $\mathrm{SFSR}_{1}$ (359.75), $\mathrm{SFSR}_{3}(324.25)$,
SFSR $_{6}$ (320.22), SFSR $_{5}$ (290.68), SFSR $_{2}$ (279.00) and $\mathrm{SFSR}_{8}$ (279.00). The isolate $\mathrm{SFSR}_{7}$ has produced minimum number of sclerotia (274 /plate) (Table 4 and Plate 5).

\section{Sclerotial size}

The biggest sclerotium $(1224 \mu \mathrm{m})$ was produced by $\mathrm{SFSR}_{1}$ isolate followed by $\operatorname{SFSR}_{3}(1080 \mu \mathrm{m})$ and $\operatorname{SFSR}_{6}(1076 \mu \mathrm{m})$. The smallest sclerotium $(1002 \mu \mathrm{m})$ was observed in $\mathrm{SFSR}_{8}$ (Table 4).

Table.1 Survey for diseases of sunflower in Tamil Nadu - Kharif 2012

\begin{tabular}{|c|l|c|c|c|c|c|}
\hline $\begin{array}{c}\text { Sl. } \\
\text { No. }\end{array}$ & \multicolumn{1}{|c|}{ Place } & $\begin{array}{c}\text { Necrosis } \\
(\boldsymbol{\%})\end{array}$ & $\begin{array}{c}\text { ALS } \\
(\mathbf{P D I})\end{array}$ & $\begin{array}{c}\text { Rust } \\
(\mathbf{P D I})\end{array}$ & $\begin{array}{c}\text { Wet root rot } \\
(\boldsymbol{\%})\end{array}$ & $\begin{array}{c}\text { Powdery } \\
\text { mildew(PDI) }\end{array}$ \\
\hline 1 & Coimbatore & 3.3 & 16.6 & Nil & 3.5 & 13.4 \\
\hline 2 & Erode & 2.7 & 13.3 & Nil & 5.0 & 10.7 \\
\hline 3 & Tiruppur & 1.6 & 19.1 & Nil & 4.2 & 20.3 \\
\hline 4. & Tuticorin & 2.4 & 17.4 & Nil & Trace & 16.1 \\
\hline 5. & Dindigul & 2.1 & 18.9 & Nil & 5.5 & 23.7 \\
\hline 6. & Tirchy & 1.0 & 15.7 & Nil & 2.8 & 17.0 \\
\hline 7. & Karur & 2.6 & 14.4 & Nil & 4.6 & 13.8 \\
\hline
\end{tabular}

Table.2 List of S. rolfsii isolates used in the study

\begin{tabular}{|c|l|l|l|}
\hline S.No & \multicolumn{1}{|c|}{ Places } & \multicolumn{1}{c|}{ District } & Isolates \\
& & & \\
\hline 1 & Bhavanisagar & Erode & SFSR1 \\
\hline 2 & Vaigai dam & Theni & SFSR2 \\
\hline 3 & Coimbatore & Coimbatore & SFSR3 \\
\hline 4 & Paiyur & Dharmapuri & SFSR4 \\
\hline 5 & Vamban & Thanjavur & SFSR5 \\
\hline 6 & AC\&RI & Madurai & SFSR6 \\
\hline 7 & Sugarcane Res. Station & Cuddalore & SFSR7 \\
\hline 8 & Manaparai & Trichy & SFSR8 \\
\hline
\end{tabular}


Table.3 Pathogenicity of $S$. rolfsii isolates on sunflower Morden and KBSH-44

\begin{tabular}{|c|c|c|}
\hline \multirow[t]{2}{*}{ Isolates } & \multicolumn{2}{|c|}{ Stem rot incidence $(\%)$} \\
\hline & Morden & KBSH44 \\
\hline SFSR1 & 46.49 & 52.32 \\
\hline SFSR2 & 48.36 & 58.31 \\
\hline SFSR3 & 55.44 & 68.82 \\
\hline SFSR4 & 38.80 & 64.15 \\
\hline SFSR5 & 40.30 & 54.71 \\
\hline SFSR6 & 32.95 & 46.59 \\
\hline SFSR7 & 30.69 & 42.58 \\
\hline SFSR8 & 24.88 & 34.60 \\
\hline SED & 1.03 & 1.38 \\
\hline $\mathrm{CD}(0.05)$ & 2.19 & 2.93 \\
\hline
\end{tabular}

Table.4 Morphological character of different isolates of S. rolfsii

\begin{tabular}{|c|l|l|c|c|c|c|c|}
\hline S.No & Isolate & $\begin{array}{c}\text { Place of } \\
\text { collection }\end{array}$ & $\begin{array}{c}\text { Colony } \\
\text { type }\end{array}$ & $\begin{array}{c}\text { Growth } \\
\text { rate } \\
\text { mm/day }\end{array}$ & $\begin{array}{c}\text { Sclerotial } \\
\text { colour }\end{array}$ & $\begin{array}{c}\text { No.of } \\
\text { sclerotia } \\
\text { / Plate }\end{array}$ & $\begin{array}{c}\text { Sclerotial } \\
\text { diameter } \\
(\boldsymbol{\mu m})\end{array}$ \\
\hline 1 & SFSR1 & Erode & Compact & 31.45 & RB & 359.75 & 1224.00 \\
\hline 2 & SFSR2 & Theni & Fluffy & 25.55 & DB & 279.00 & 1020.00 \\
\hline 3 & SFSR3 & Coimbatore & Fluffy & 27.52 & DB & 324.25 & 1080.00 \\
\hline 4 & SFSR4 & Dharmapuri & Compact & 21.62 & DB & 360.00 & 1064.00 \\
\hline 5 & SFSR5 & Thanjavur & Compact & 22.60 & LB & 290.68 & 1004.00 \\
\hline 6 & SFSR6 & Madurai & Fluffy & 26.53 & DB & 320.22 & 1076.00 \\
\hline 7 & SFSR7 & Cuddalore & Compact & 24.57 & RB & 274.00 & 1010.00 \\
\hline 8 & SFSR8 & Trichy & Compact & 23.58 & RB & 279.00 & 1002.00 \\
\hline & & & SED & 0.0035 & & 12.96 & 45.89 \\
\hline & & & CD (0.05) & 0.0073 & & 27.47 & 97.29 \\
\hline
\end{tabular}


Fig.1 Pathogenicity of $S$. rolfsii isolates on sunflower (Morden and KBSH- 44)
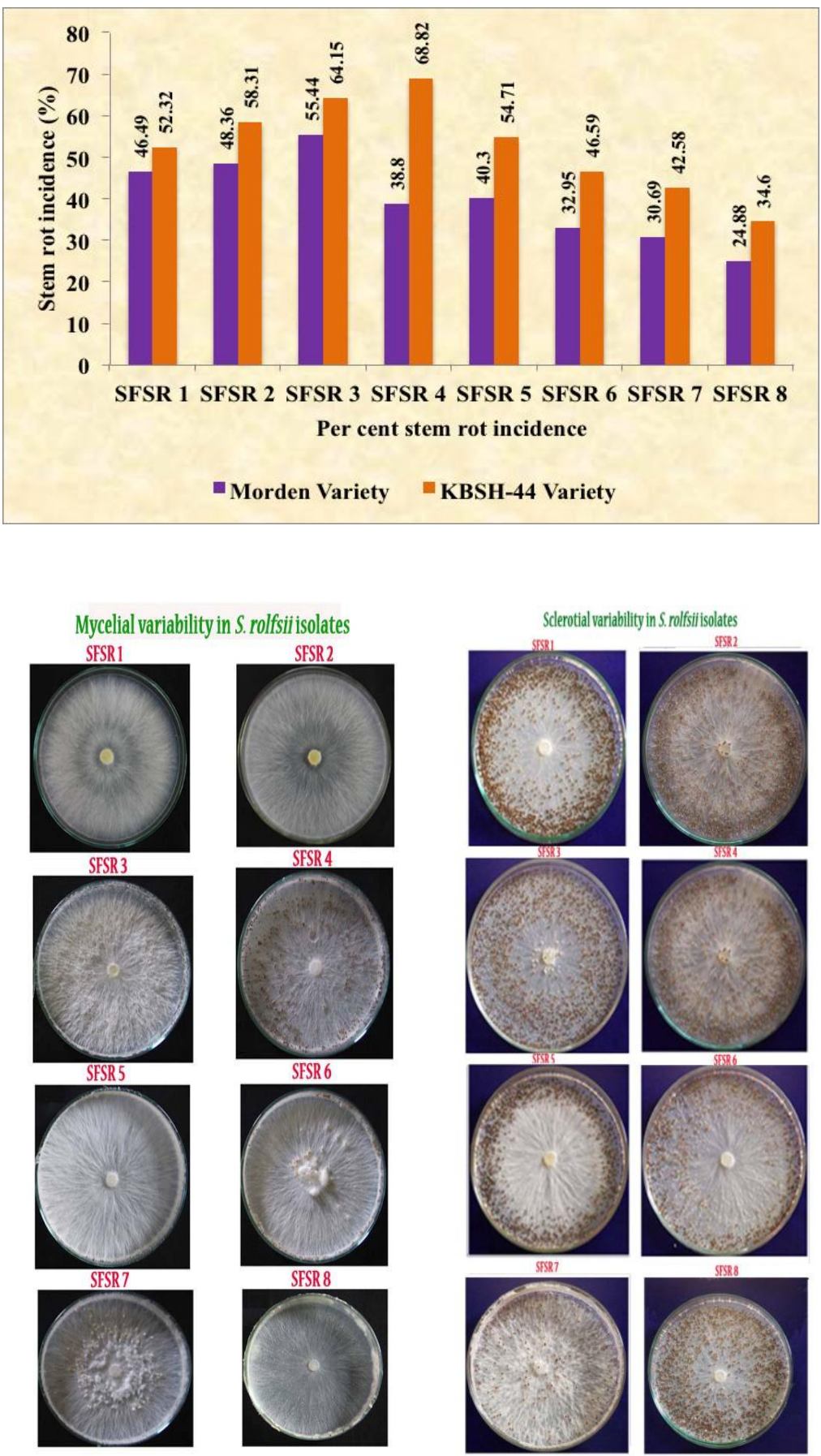

Morphological characters of the isolates

\section{Colony type}

All the eight isolates of $S$. rolfsii varied in all of the morphological character among the

eight isolates, three isolates were with fluffy colonies, and 5 isolates were compact in the present study. While only one isolate $\left(\mathrm{SFSR}_{1}\right)$ was fast growing type $(31.45 \mathrm{~mm} /$ day $)$ and other isolates recorded only 21.62 to 27.52 $\mathrm{mm} /$ day growth. Shantha lakshmi Prasad et 
al., (2012) have collected 22 isolates of $S$. rolfsii in sunflower from southern states of India and the isolates of $S$. rolfsii varied in growth parameters i.e., colony morphology, mycelial growth rate, colony colour, sclerotial production, number and size of sclerotia. The fungus produced white cottony mycelium with ropy strands. Out of 22 isolates, colonies of 12 were fluffy and wooly, whereas 10 were compact. The growth rate of the isolates varied substantially. Isolates $\mathrm{Sr}-2, \mathrm{Sr}-5, \mathrm{Sr}-9$, Sr-11 and Sr-16 were fast growing (81-90 $\mathrm{mm}$ ) while the isolates Sr-1, Sr-3, Sr-4, Sr-10, Sr-13, Sr-14 and Sr-17 were slow growing $(30.6-50 \mathrm{~mm})$. Others were medium in growth, which varied from 51 to $80 \mathrm{~mm}$ in diameter. Though the isolates from different areas like Sr 5 \& Sr 6; Sr 10 \& Sr 11; Sr 18 \& $\mathrm{Sr} 19, \mathrm{Sr} 21$ and $\mathrm{Sr} 22$ may be morphologically similar, the variation in growth could be due to differences in ecology, genetic differences or the nutrient level of the soil (Okereke and Wokocha, 2007).

\section{Sclerotial production, size and colour}

Production of sclerotia among isolates varied significantly. Most of the isolates produced number of sclerotia which varied from 274 to 360 sclerotia /plate. The size and colour of sclerotia varied in different isolates. The average size of the sclerotia in most of the isolates varied from $1004.00 \mu \mathrm{m}$ to 1224.00 $\mu \mathrm{m}$ in diameter. The colour of the sclerotia was mostly light brown to reddish brown at maturity (Table 4). All the eight isolates possessed the morphological character pertinent to $S$. rolfsii described by Aycock (1966). Sharma et al., (2002) also reported variations in the colony type, growth rate sclerotial colour, sclerotial number and sclerotial size among the isolates of $S$. rolfsii causing root rot of various hosts.

Although the majority of the isolates showed profuse mycelial growth, high sclerotial size and number, $\mathrm{SFSR}_{1}$ isolate was found to be highly virulent ranked first in the number of sclerotia per plate and mycelial growth rate. This is in confirmation with the report of Komathi (2002) who reported that highly virulent strains exhibited very rapid growth and produced huge number of sclerotia in the culture. Shantha lakshmi Prasad et al., (2012) reported that the fungus was characterized by the production of small spherical sclerotia with internally differentiated rind, cortex and medulla. The fungus produced sclerotia at the edges of the Petri plates from 11 days up to 25 days after inoculation at $28^{0} \mathrm{C}$ when the agar media were completely covered with mycelia. Production of sclerotia varied among isolates. Some isolates produced more number of sclerotia (>200/plate), while majority of the isolates produced fewer sclerotia $(<200$ /plate). The number of sclerotia was more in isolates Sr 11 (306) followed by $\mathrm{Sr} 5$ (267) and Sr 6 (260). Less number of sclerotia was observed in isolate $\mathrm{Sr}$ 3 (57) followed by $\mathrm{Sr} 10(68)$ and $\mathrm{Sr} 7$ (73). The sclerotia were small and uniformly round. The colour of sclerotia of isolates was generally dark to reddish brown at maturity, while sclerotia were light brown in some isolates.

\section{References}

Anonymous, 2012. All India Co ordinated Research Project on Oil seeds, Directorate of Oil seeds Research, Hyderabad

Ansari, M.M. 2005. Management of collar rot of soybean through biological agents. Plant Disease Res., 20(2): 171-173.

Aycock, R. 1966. Stem rot and other diseases caused by $S$. rolfsii. North Carolina Agricultural Experimental Station Technical Bulletin, 174: 202.

Garren, K.H. 1961. Control of S. rolfsii through cultural practices. Phytopathology, 51: 120-124. 
Komathi, K. 2002. Studies on biological management of root rot of groundnut (Arachis hypogaea L.) caused by Sclerotium rolfsii. M.Sc. (Ag.) Thesis, Agricultural College and Research Institute, Tamil Nadu Agricultural University, Madurai

Mehan, V.K. and McDonald, D., 1990. Some important diseases of groundnut, sources of resistance and their utilization in crop improvement. Paper Presented in Country Training Course on Legumes Production, 9-17 July, 1990, Sri Lanka.

Okereke, V.C. and Wokocha, R.C. 2007. In vitro growth of four isolates of Sclerotium rolfsii in the humid tropics.
African Journal of Biotechnology, 6(16): 1879-1881.

Rangaswami, G. 1972. Diseases of crop plants in India. Prentice Hall of India Pvt. Ltd., New Delhi, 520 pp.

Santha Laskhmi Prasad, M.K. Sujatha, N. Naresh and S. Chander Rao. 2012. Variability in Sclerotium rolfsii associated with collar rot of sunflower. Indian Phytopathology. 65(2): 161-165.

Sharma, B.K., Singh, U.P. and Singh, K.P. 2002. Variability in Indian isolates of Sclerotium rolfsii. Mycologia, 94(6): 1051-1058.

\section{How to cite this article:}

Karthik pandi, V., C. Gopalakrishnan and Janahiraman, V. 2017. Cultural and Morphological Variability in Sclerotium rolfsii causing Stemrot Disease. Int.J.Curr.Microbiol.App.Sci. 6(6): 3090-3097. doi: https://doi.org/10.20546/ijcmas.2017.606.366 